\title{
PERCEPTIONS AND USAGES OF ONLINE TEACHING RESOURCES BY SOUTH DAKOTA SCIENCE AND AGRICULTURE TEACHERS
}

\author{
P. Troy White ${ }^{1, *}$, Madhav P. Nepal ${ }^{2, *}$, Mercedes Lemke ${ }^{1}$, \\ Larry B. Browning ${ }^{3}$, Matthew L. Miller ${ }^{4}$, and Sharon Vestal ${ }^{5}$ \\ ${ }^{1}$ Department of Teaching, Learning \& Leadership \\ ${ }^{2}$ Department of Biology and Microbiology \\ ${ }^{3}$ Department of Physics \\ ${ }^{4}$ Department of Chemistry and Biochemistry \\ ${ }^{5}$ Department of Mathematics \& Statistics \\ South Dakota State University, \\ Brookings, South Dakota, 57007 \\ *Corresponding authors'emails: Madhav.Nepal@sdstate.edu \\ and Peter.White@sdstate.edu
}

\begin{abstract}
Understanding how teachers utilize, adapt, and integrate curriculum is helpful in the development and dissemination of curricular resources to better serve teachers' needs. Agricultural and science educators face similar challenges in selecting, adapting, and delivering curricular content in their courses. The data presented here assess teachers perceptions and usage of online curricular resources by agriculture and science teachers in K-12 classrooms. The specific research objectives were to 1 ) determine the teacher's perceptions and usage of online curriculum resources and 2) determine the methods they use to locate and select web-based curricular resources. Analysis suggests that the curricular needs and utilization may not be discipline-specific, and that needs identified in other disciplines may have applications in agriculture and science classrooms. Teachers utilized Google, Facebook, and other social media platforms to share and locate resources, but expressed the need to have better organization and classification of online resources. Resources need to be tagged with state and national standards, have references, and activities that are engaging for students and easily adaptable to teachers' local needs and styles. Teaching pre-service teachers to better utilize existing curricular resources could lead to improved instruction and student learning while saving time. Further research into the utilization of existing curriculum by both current and preservice teachers is warranted.
\end{abstract}

Keywords

Secondary Education, science, agriculture, and curriculum 


\section{INTRODUCTION}

Agricultural and science educators need to be prepared to teach students in an ever-changing world. Curriculum planning is perhaps one of the most important tasks a teacher must perform before instruction (Maull et al. 2010). Agricultural educators looking for new resources to use in their curriculum have a wide array of choices from the free NAAE (National Association of Agricultural Educators) Communities of Practice to pre-packaged all-in-one solutions like CASE (Curriculum for Agricultural Science Education) and MyCAERT. However, specific curricular content may be difficult to find, requiring teachers to create original materials with little to no background or no experience in the new content areas. The Next Generation Science Standards (NGSS), which most dual-certified agriculture and science courses are required to meet, leave teachers with challenges in finding lessons aligned to both Agriculture, Food, and Natural Resource (AFNR) standards and the NGSS. Understanding how and where teachers look to meet AFNR and NGSS standards is a vital first step to providing teachers with quality resources in a timely fashion.

Curriculum is a core component of teaching and learning contexts (Fishman et al. 2013). In the first years of teaching, teachers must decide whether to find curriculum online or through other resources. Rural agriculture teachers are increasingly teaching agriculture courses for science credit. Historically, rural science education "described science as an activity that would revolutionize farming and all aspects of life in a rural setting in terms of knowledge and attitude" (Oliver and Hodges 2014). Technology changed the way rural science education was taught within and outside of the classroom. The use of technology to access knowledge and other resources has gained traction over the years (Avery 2013). Online or other distance-delivered learning in rural classrooms has increased course options for students. However, the implementation of online distance education in rural areas is more difficult than in urban and suburban schools due to limited online access, resources, professional development, and access to technical support (Oliver and Hodges 2014). This leads to teachers in rural settings teaching a wide variety of classes, some of which they have limited experiences in or are not comfortable teaching, causing teachers to look for high-quality resources, curricula, or teaching aids to be able to deliver effective instruction to their students.

Rural students may be better than their suburban peers in their connectedness to both science and agriculture (Avery and Kassam 2011). Science as the foundation of agricultural courses for students is not a new idea (True 1897; Shepardson 1929). Thompson (1998) stated: "The educational reform movement has led to rapid changes in education and agricultural education" (p. 77). Among these rapid changes was a renewed focus on the scientific side of agricultural and natural resource education and the emergence of the term Agriscience (Hillison 1996). Budke (1991) stated, "agriculture provides a marvelous vehicle for teaching genetics, photosynthesis, nutrition, pollution control, water quality, reproduction, food processing where real live examples can become part of the classroom for experimentation and observation." 
Agriscience researchers reported that compared to students in traditional science classes, students in integrated agriscience classrooms had an increased understanding of science concepts (Thompson 1998) and increased science achievement scores (Enderlin and Osborne 1992). Other researchers found positive relationships between the number of agriscience courses completed and science test scores (Ricketts et al. 2006). In addition, agriscience students were more likely to become successful in state-mandated science tests than non-agriscience students (Chiasson and Burnett 2001). Finally, participating in biology classes that use an agricultural context helped students understand relationships between agriculture and science (Balschweid 2002). Given the benefits of integration, we acknowledge there are also limitations. Scales et al. (2009) reported that agriculture teachers may not be fully prepared to teach agriscience. Additionally, Haynes et al. (2012) found that while improvement could be made in science achievement, it was limited. Given the positive and cautionary studies cited herein, it becomes apparent that to increase the integration potential of both science and agriculture courses, quality curriculum and resources are needed.

While the development of high-quality resources for agriscience content may have an impact on rural science and agricultural content, that impact may be mitigated due to the ineffective design and distribution of curricular resources. Despite national efforts to develop high-quality science-based resources for agricultural education and the increasing emphasis for science educators to find real-world regionally relevant content (Donovan and Bransford 2005; Honey et al. 2014), limited research into the curricular preferences of secondary educators can be found in the literature of the discipline. Broadening searches to other educational disciplines and all grade-levels yields some insight into how teachers in general find and evaluate curriculums.

Kerr (1981) reported that "prescriptive models of how instructional design should proceed frequently do not match the reality of instructional design in practice" (p. 363). Kerr also reported that workshop participation led to the creation of specific content to be utilized in specific courses. Kerr concluded that teachers frequently first think of activities and other elements of teaching before considering objectives. "It's an art-an art of selection and arrangement" (p. 376). Ball and Feiman-Nemser (1988) reported that elementary student teachers' preservice courses impacted the utilization of textbooks and teacher's guides with students reporting that good teachers should avoid the use of these resources as they negatively impact both teaching and knowledge acquisition. Ball and Cohen (1996) suggest that teachers' necessity to select and adapt the curriculum to individual students creates gaps between what curriculum developers intend and what is taught in the classroom. Schneider and Krajcik (2002) suggested that curriculum materials that both provide content and education for the teacher beyond the level needed by students may be more effective. They found prior content and pedagogical differences impacted both the degree of utilization and types of resources teachers utilized, with some teachers focusing instruction on teaching to the assessments contained in the curriculum and some teachers not seeing the larger picture or direction of the curriculum. Taylor et al. (2015) suggested that teacher adaptation and selective use of curricular materials led to 
fragmented understanding and frequent duplication of materials in the larger sequences of courses.

Given that teachers may feel that curriculum which they do not create themselves is not as effective as content they develop themselves, leading to the sporadic adoption of only parts of an existing curriculum, the question arises, how does the digital age impact teacher selection of curricular resources? What resources are teachers accessing? What types of curricular resources would benefit teachers? Do the factors identified through related disciplines apply to agricultural education, and what other discipline-specific factors may exist in school-based agricultural and science education? Does an increased emphasis on standards impact teachers' selection choices?

Conceptual Frameworks-The conceptual framework for this study was adapted from the work of Charalambous and Hill (2012) in mathematics. They posited that effective teaching is a combination of curriculum and teacher knowledge, a concept they termed Mathematical Knowledge for Teaching and which we term Agri-Scientific Knowledge for Teaching (AKT). This encompasses the knowledge needed to effectively teach scientific agriculture, including an understanding of the scientific processes and their application to agriculture. This framework suggests that curricular decisions are a combination of both prior content knowledge and prior content-specific pedagogical knowledge. Charalambous and Hill integrated two traditionally distinct lines of research, showing that both content knowledge of the teacher and their knowledge of content-specific pedagogy combined for more effective student learning outcomes. To help bridge the gap between available curriculums and teacher utilization of the available curriculums, the study reported here addressed how rural science and agricultural educators locate and select curricular resources, a first step in helping increase AKT through improving the efficiency of the curriculum knowledge of rural teachers.

Purpose and Objectives-Rapid dominance of technology in today's societies is revolutionizing our teaching and learning processes. Purcell et al. (2013), through a national survey, showed a wide usage of technology by teachers at home and in their classrooms. The results also showed that many of these high school and middle school teachers worried about digital divides regarding student access to technology particularly in the school districts with low-income students (Purcell et al. 2013). The purpose of this study was to evaluate agriculture and science teachers' perceptions of online curriculum and its usage in agriculture and science classrooms in South Dakota. The specific research objectives of this study were to 1) determine agriculture and science educators' perceptions and usage of online curriculum resources, including web-based curriculum resources, and 2) determine methods the teachers utilize to locate and evaluate web-based curricular resources.

\section{METHODS}

This study utilized a mixed methods approach. Before a summer professional development workshop, all the science and agriculture teachers $(N=391)$ with 
publicly available email addresses in South Dakota were contacted, inviting them to participate in an electronic survey designed to collect descriptive data related to curriculum and particularly online curriculum preferences. Science and agriculture teachers were both included due to their related content, similar issues regarding distance from other teachers teaching the same discipline, and the fact that due to the similarity of content, agriculture teachers in smaller schools in the region commonly teach science courses. In addition, several science teachers are teaching agriculture and environmental science courses for career and technical education credit. The study was certified as exempt by the university's institutional review board (IRB\# 1705011-EXP).

A questionnaire (see Appendix 1) was developed for use in this study. The first section of the survey included demographic variables related to community size, gender, grade levels taught, certifications held, and dual credit offerings. The majority of the second section included open-ended questions concerning general course delivery and curricular resources selection. Teachers were asked what crossover content they taught (agriculture in science, science in agriculture), where they looked for curricular resources, how they evaluated the credibility of resources, and the frequency of using social media platforms to locate curricular content. The third section asked teachers to rate items for their degree of importance when selecting curriculum, and impact on selection of lessons. The final section had questions about the use of guest speakers, inquiry-based projects, science fairs, in-service training, and general comments about the topic of curriculum selection and delivery that they would like curriculum developers to know about that was not covered in prior questions. The last question asked on the questionnaire was whether teachers would be interested in participating in a professional development workshop the following summer which would include a focus on connecting rural teachers and their communities with university faculty as content area experts. Teachers who signed up and attended the summer workshop served as the convenience sample for follow-up face-to-face interviews. As a component of the workshop, qualitative focus group interviews were conducted with the fifteen teachers in attendance at the workshop. Teachers attending the workshop were divided into two groups, and semi-structured interviews were utilized to discuss the teachers' curriculum and web accessing preferences. Interviews were transcribed and common themes emerging from both groups are reported herein. Both groups were a mixture of both science and agriculture teachers who reported teaching from middle school through 12th grade.

Questionnaire responses $(n=107)$ were collected for three weeks with weekly reminder emails being sent through the survey application. Incomplete responses were defined as those not completing more than one section of the questionnaire. Removal of incomplete responses left 85 usable responses for a response rate of $21.7 \%$. Early (first day responders, $n=36)$ and late $(n=49)$ responses were compared using an independent samples t-test, and no significant $(P=0.21, d=$ -0.28) differences were found for the demographic variable "years of teaching," indicating the two groups were similar, and the results could be generalized to science and agriculture educators in the state (Lindner et al. 2001). 


\section{RESULTS AND DISCUSSION}

Survey respondents were predominantly female $(59.15 \%, n=42)$, from rural farming communities $(61.19 \%, n=41)$, and taught at a school of more than 301 students $(60.27 \%, n=44)$. Respondents reported teaching an average of 16.38 years, $S D=11.10$. This suggests that teachers' persistence among these rural science and agricultural educators is higher than the current national average (Ingersoll et al. 2018).

Less than $42 \%$ of teachers reported never using social media for educational purposes (see Figure 1). Using social media for educational purposes one to three times a month was the most common usage at $35.2 \%$ by teachers with $14.1 \%$ of teachers reporting they used social media for educational purposes multiple times a week, but with no teacher reporting using social media daily for educational purposes. Evidence shows that effective use of curriculum materials requires teacher's ability to mobilize a variety of personal and curricular resources to promote student learning (Forbes and Davis 2010). Previous research (Prestridge 2019) found that increased use of social media by teachers enhanced teachers professional learning and conceptualizations. Prestridge suggested that social media platforms be included in professional development workshops. Moore and Chae (2007) described beginning teachers' utilization of online resources in professional tasks and teaching practice, reporting that teachers used internet search engines to locate the online teaching resources.

Respondents reported using a variety of social media applications for education use with Facebook being used the most frequently $(42.4 \%, n=36)$, followed by professional learning communities at $34.1 \%$ (see Table 1). Other social media applications that teachers reported using included Google, Pinterest, and Edmodo.

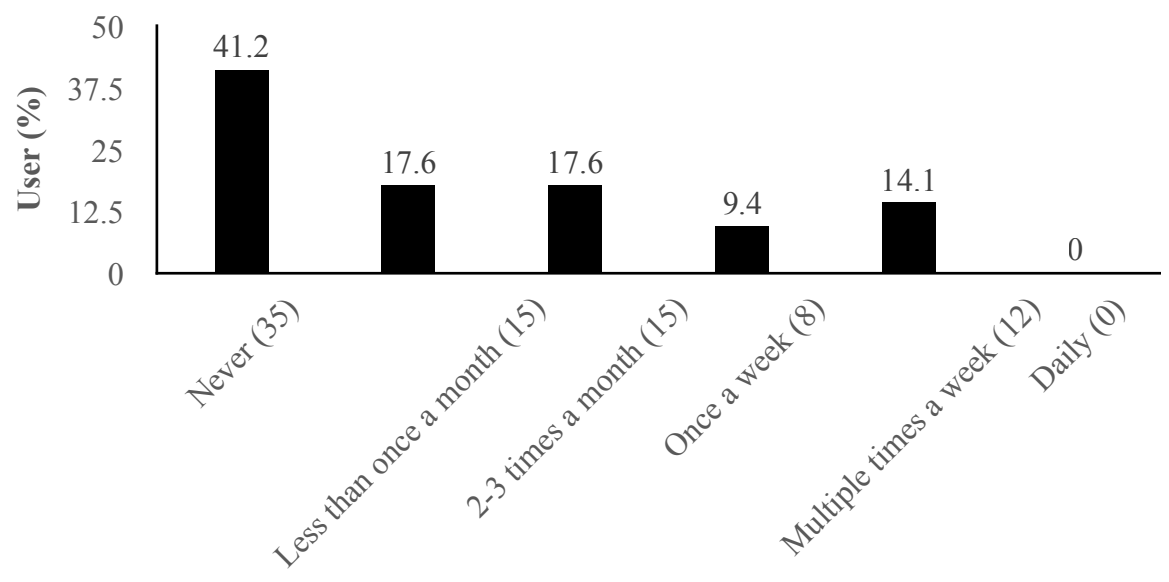

Figure I. Social media usage for educational purposes (Total respondents $\mathbf{8 5}$ ). 
Table I. Respondents social media application usage for educational purposes $(n=85)$.

\begin{tabular}{lcc}
\hline Application & Number of Responses & Percent \\
\hline Facebook & 36 & 42.4 \\
Online Professional & 29 & 34.1 \\
Learning Communities & 14 & 16.5 \\
Twitter & 14 & 16.5 \\
Snapchat & 13 & 15.3 \\
Blogs & 9 & 10.6 \\
Instagram & & \\
\hline
\end{tabular}

The key components teachers reported looking for in online resources included a wide array of factors, with several being mentioned most frequently, including ease of use, adaptability, ability to interest or engage the students, and degree it related to the content they were already using. Other factors they listed included completeness, relevance to standards, current local facts and connections, inclusion of labs or activities, and visuals.

Factors teachers consider when evaluating credibility included reliable sites with multiple teachers reporting looking for curriculum on sites with .edu, gov, or .org before resorting to .com sites. Teachers reported frequently checking author affiliations and credentials, sponsoring organizations, inclusion of facts with activities, and the citation of references. Teachers frequently mentioned avoiding sites whose information didn't align with the majority of other sites they checked or those that appeared to have bias or agendas.

While teachers use a great many sources for creating, altering, and adopting curriculum, simply searching a topic by using Google was by far the most common way teachers reported finding curriculum. When viewed through the conceptual framework of this study, this suggests that for teachers to impact learning most effectively, they will need AKT to be able to quickly assess the quality and credibility of the resources they locate. Additionally, if the resources aren't indexed by Google, then most teachers will not find them. While textbooks were mentioned as a source for curriculum, agriculture and science teachers in this study appear to have similar feelings to those reported by Ball and Feiman-Nemser (1988), since textbooks received mention by only a few teachers. It should be noted that perhaps the questionnaire emphasis on online and digital sources may have discouraged the mentioning of print sources, whose utilization could be higher than teacher comments suggested.

Use of social media to distribute curriculum resources has potential. Many teachers (over 40\%) reported using social media, specifically Facebook, in relation to their teaching, even more than reported using professional learning communities. Given the resources that learning communities like Communities of Practice have available compared to companies like Facebook, it could prove beneficial to evaluate the two sources to determine if their integration could occur, and what such a partnership should look like. More detailed assessments of 
both social media platforms to determine where overlaps occur and what unmet needs one has over the other could benefit teachers. Research into methods for better utilization of both platforms, metadata and other tagging processes, and improved searchability is needed.

Teachers were asked to rate the importance of selected factors on both their curriculum selection (see Table 2) and specific content in the curriculum (see Table 3).

Table 2. Importance of selected criteria in curriculum choices.

\begin{tabular}{|c|c|c|c|c|c|c|c|c|c|c|c|c|c|}
\hline \multirow[b]{2}{*}{ Statement } & \multirow[b]{2}{*}{$n$} & \multirow[b]{2}{*}{ Mean } & \multirow[b]{2}{*}{ SD } & \multicolumn{6}{|c|}{ No importance } & \multicolumn{4}{|c|}{$\begin{array}{c}\text { Great deal } \\
\text { of importance }\end{array}$} \\
\hline & & & & 1 & 2 & 3 & 4 & 5 & 6 & 7 & 8 & 9 & 10 \\
\hline $\begin{array}{l}\text { Relevance to } \\
\text { your students }\end{array}$ & 82 & 8.72 & 1.72 & 2 & 0 & 0 & 0 & 1 & 4 & 3 & 20 & 17 & 35 \\
\hline $\begin{array}{l}\text { Relevance to } \\
\text { your community }\end{array}$ & 82 & 8.01 & 1.73 & 1 & 1 & 1 & 1 & 2 & 2 & 16 & 21 & 25 & 12 \\
\hline $\begin{array}{l}\text { Comprehensiveness } \\
\text { of the resources }\end{array}$ & 83 & 7.75 & 2.11 & 3 & 0 & 4 & 0 & 3 & 4 & 10 & 24 & 23 & 12 \\
\hline $\begin{array}{l}\text { Degree of comfort } \\
\text { with the content }\end{array}$ & 83 & 7.41 & 1.93 & 1 & 2 & 1 & 1 & 7 & 8 & 21 & 14 & 19 & 9 \\
\hline $\begin{array}{l}\text { Tied to state } \\
\text { standards }\end{array}$ & 80 & 7.09 & 2.52 & 4 & 1 & 5 & 3 & 7 & 6 & 10 & 15 & 17 & 12 \\
\hline $\begin{array}{l}\text { Prior personal } \\
\text { experience with the content }\end{array}$ & 83 & 6.86 & 2.30 & 3 & 2 & 6 & 0 & 10 & 6 & 17 & 19 & 13 & 7 \\
\hline $\begin{array}{l}\text { Tied to national } \\
\text { standards }\end{array}$ & 82 & 5.83 & 2.70 & 8 & 4 & 9 & 6 & 8 & 4 & 12 & 19 & 9 & 3 \\
\hline
\end{tabular}

Teachers reported that prior experience and comfort were important in their selection of curriculum, but not as important as standards. Both experience and standards were not considered as important as relations of resources to the students and communities in which the teachers were located. When asked about the specific topics they included, personal experiences and knowledge of the subjects rated slightly higher than relation to the standards. Coupled with teachers reporting that adaptability was one of the primary qualities they looked for in resources, this finding is in alignment with the work of Schneider and Krajcik (2002) who posited that prior content and pedagogical knowledge played a prominent role in the way teachers utilized and adapted curricular resources. 
Table 3. Factors impacting the selection of content in respondents' curriculum.

\begin{tabular}{|c|c|c|c|c|c|c|c|c|c|c|c|c|c|}
\hline \multirow[b]{2}{*}{ Statement } & \multirow[b]{2}{*}{$n$} & \multirow[b]{2}{*}{ Mean } & \multicolumn{6}{|c|}{ No importance } & \multicolumn{5}{|c|}{$\begin{array}{c}\text { Great deal } \\
\text { of importance }\end{array}$} \\
\hline & & & SD & 1 & 2 & 3 & 4 & 5 & 6 & 7 & 8 & 9 & 10 \\
\hline $\begin{array}{l}\text { Prior experience } \\
\text { with the topic }\end{array}$ & 82 & 7.16 & 2.01 & 1 & 3 & 0 & 4 & 7 & 10 & 17 & 17 & 16 & 7 \\
\hline $\begin{array}{l}\text { Comfort with } \\
\text { the topic }\end{array}$ & 82 & 7.09 & 2.05 & 2 & 0 & 3 & 1 & 12 & 12 & 14 & 15 & 14 & 9 \\
\hline $\begin{array}{l}\text { Listed in the state/ } \\
\text { national standards }\end{array}$ & 82 & 6.79 & 2.38 & 3 & 1 & 5 & 4 & 14 & 5 & 11 & 16 & 14 & 9 \\
\hline
\end{tabular}

Additionally, teachers were asked to name the five locations they visited most frequently in selecting new curriculum content for their courses. The most frequent digital response was Google. Other frequently mentioned locations included other teachers, professional organization websites, publisher websites, other teachers published websites (both free and pay sites like Teachers Pay Teachers), government websites like NASA and USDA, university websites, Extension, PBS, Ted Talks, journal articles, and YouTube. Traditional print sources were also mentioned, with books, magazines, and conference handouts being the most popular.

Teachers reported relevance to their existing curriculum and state standards as primary factors in their selection of resources. Curricular resources published for teachers must show clear relevance to students and be aligned to searchable state and national standards. State standards were more important than national standards for teachers in this study. Since many states publish separate standards from those published nationally, it is important that any curricular resources intended for national audiences include the ability to be tagged for both state and national standards, or that state teacher associations create crosswalks which delineate which national standards are equivalent to their state standards, and that those be listed on the same sites on which the resources are posted to further eliminate the need for teachers to go to multiple sites to meet their curriculum needs.

Guest speakers were utilized by $80 \%$ of respondents $(n=68)$ to cover new or emerging topics. Half of the respondents $(50.1 \%)$ reported bringing in guest speakers only once a semester, with $31.8 \%$ utilizing guest speakers two to three times a semester. Teachers reported using guest speakers primarily as experts who could bring relevance to the topics the teacher was teaching. Teachers also mentioned guest speakers brought more accurate or up to date information, hands-on experiences, first-hand knowledge, and career experiences. The use of guest speakers is nearly ubiquitous among both science and agriculture teachers.

Utilization of digital resources and the ability to bring virtual guests into rural classrooms should not be overlooked. Despite both groups' high utilization of face to face guest speakers, neither group reported high utilization of distance technology to bring in remote guest speakers $(\mathrm{Ag}=25 \%$, Science $=13.3 \%)$. 
Given the time constraints teachers reported being under, it may be beneficial to create a resource to which content experts can post content and contact information for teachers. Creating a resource where this can be seamlessly integrated into an existing platform would ensure that teachers wouldn't have to go to one more location to find virtual guest speakers. Although inviting guest lectures in university classrooms is very common (LeBlanc and Dyer 2003), inviting guest lectures in the high school classrooms is not; however, our teachers seem to be forward-looking in terms of using available expertise through university extension and outreach as well as through professional societies.

In follow-up focus group interviews with teachers, responses about organizational structures that teachers look for in curriculum sites included a limited number of clicks to get to information, all-inclusive but easily adaptable lessons, photographs of lab activities, ease of navigation, and consistency of content. Teachers pointed out that while online learning communities had a great deal of content, it was hard to find, inconsistent in its quality, and not searchable by standards or established content topics. Teachers also wanted to be able to comment on the quality of the resources and to be able to change content and then discuss the changes and impacts on students with others who are utilizing the same content. They reported that minimizing the number of platforms they need to search to find high-quality resources would be beneficial. Having multiple versions of a resource that teachers have edited, discussed, and possibly even rated could benefit teachers, and reduce the time they spend looking for resources. Posting resources in editable formats is a must for busy teachers. In addition, being able to quickly scan through comments on a series of postings all based on one original resource and its multiple renditions would allow teachers to find resources which more closely align to their teaching style, content focus, or situation. Having one resource with all iterations at one click would help meet teachers' desire to eliminate sorting through multiple sites of seemingly similar content.

Recommendations from this study include: 1) further definition and metrics of the AKT of the current and preservice teachers need to be established, 2) teachers need a one stop location which houses curriculum resources tagged by national and state standards, content topics, easily searchable, reviewed and updated for content and accuracy, 3) teaching preservice teachers how to utilize existing curricular resources effectively, and spending more time on pedagogy will improve both the quality of teaching and student outcomes and 4) further research on how teachers access and utilize existing curricular resources would yield better insights into planning and implementing effective professional development workshops for teachers.

Further work needs to be conducted which establishes the essential components of AKT, and how teacher preparation programs can help future teachers develop this level of knowledge. Teachers described scanning curricular resources for content accuracy, alignment with their current curriculum, and ability to engage students with the content. Helping preservice teachers gain a deeper understanding for this process may lead to reductions in time spent developing curriculum, improving content, and enabling candidates to spend more time focusing on pedagogy. Taylor et al. (2015) suggest that ongoing teacher professional development 
in concert with research-based curriculum be considered as a standard and should lead to improved pedagogy and student outcomes. Providing early interventions targeted at teaching preservice teachers how to utilize existing curricular resources and to modify them to meet local needs could lead preservice teachers to assimilate the practices of their profession more effectively while avoiding what Taylor et al. (2015) term fragmented, incoherent, non-sequential instruction. Teacher preparation programs which explicitly teach preservice teachers more effective methods to locate and modify curricular resources will help them save time and locate resources which better align to their content and pedagogical approaches.

Recker et al. (2007) found that professional development workshops on finding online resources had positive impacts on teacher efficiency in using online learning resources. This underlies the fact that professional development programs should focus on developing skills in teachers on the effective identification and utilization of on-line curriculum resources in their classrooms. Despite professional development efforts to create curriculum, the message from teachers was that it was too scattered, too hard to locate in a timely manner, and that the quality varied greatly. They also desired the tools to rank or comment on the quality of the plethora of free resources available.

\section{ACKNOWLEDGEMENTS}

The research project is part of Immersive Learning Experiences and Rural Networking (iLEARN) professional development project supported by the USDAAFRI Education Literacy Initiative (Award \# 2017-68010-25956). Co-author Mercedes Lemke is an undergraduate researcher, who significantly contributed to this project by analyzing data as well as preparing first draft of this manuscript.

\section{LITERATURE CITED}

Avery, L.M. 2013. Rural science education: Valuing local knowledge. Theory Into Practice 52(1):28-35. https://doi.org/10.1080/07351690.2013.743769 Avery, L.M., and K.-A. Kassam, 2011. "Phronesis": Children's local rural knowledge of science and engineering. Journal of Research in Rural Education, 26(2). Available at http://jrre.vmhost.psu.edu/wp-content/uploads/2014/02/26-2.pdf [Cited 5/20/2015].

Ball, D.L., and D.K. Cohen. 1996. Reform by the book: What is-or might be-the role of curriculum materials in teacher learning and instructional reform? Educational Researcher 25(9):6-14. https://doi. org/10.3102/0013189x025009006

Ball, D.L., and S. Feiman-Nemser. 1988. Using textbooks and teachers' guides: A dilemma for beginning teachers and teacher educators. Curriculum Inquiry 18(4):401-423. https://doi.org/10.2307/1179386

Balschweid, M.A. 2002. Teaching biology using agriculture as the context: Perceptions of high school students. Journal of Agricultural Education 43(2):5667. https://doi.org/10.5032/jae.2002.02056 
Budke, W.E. 1991. Agricultural science- striving for excellence. The Agricultural Education Magazine 4:11.

Charalambous, C.Y., and H.C. Hill. 2012. Teacher knowledge, curriculum materials, and quality of instruction: Unpacking a complex relationship. Journal of Curriculum Studies 44(4):443-466. https://doi.org/10.1080/00220272.2 011.650215

Chiasson, T.C., and M.F. Burnett. 2001. The influence of enrollment in agriscience courses on the science achievement of high school students. Journal of Agricultural Education 42(1):61-71. https://doi.org/10.5032/ jae.2001.01061

Donovan, M.S., and J.D. Bransford. 2005. How Students Learn: Science in the Classroom. The National Academies Press, Washington, DC.

Enderlin, K.J., and E.W. Osborne. 1992. Student achievement, attitudes, and thinking skill attainment in an integrated science/agriculture course. 19th Annual National Agricultural Education Research Conference of the American Association for Agricultral Education, St. Louis, MO.

Fishman, B., S. Konstantopoulos, B.W. Kubitskey, R. Vath, G. Park, H. Johnson, and D.C. Edelson. 2013. Comparing the impact of online and face-to-face professional development in the context of curriculum implementation. Journal of Teacher Education 64(5):426-438. https://doi. org/10.1177/0022487113494413

Forbes, C.T., and E.A. Davis. 2010. Curriculum design for inquiry: Preservice elementary teachers' mobilization and adaptation of science curriculum materials. Journal of Research in Science Teaching 47(7):820-839. https://doi. org/10.1002/tea.20379

Haynes, J.C., J.S. Robinson, M.C. Edwards, and J.P. Key. 2012. Assessing the effect of using a science-enhanced curriculum to improve agriculture students' science scores: A causal comparative study. Journal of Agricultural Education 53(2):15-27. https://doi.org/10.5032/jae.2012.02015

Hillison, J. 1996. The origins of agriscience: Or where did all that scientific agriculture come from? Journal of Agricultural Education 37(4):8-13. https:// doi.org/10.5032/jae.1996.04008

Honey, M., G. Pearson, and H. Schweingruber. 2014. STEM integration in k-12 education: Status, prospects, and an agenda for research. The National Academies Press, Washington, DC. https://doi.org/10.17226/18612

Ingersoll, R.M., E. Merrill, D. Stuckey, and G. Collins. 2018. Seven trends: The transformation of the teaching force - updated October 2018. CPRE research reports. Consortium for Policy Research in Education. Available from https://repository.upenn.edu/cpre_researchreports/108 [Cited 11/20/2018].

Kerr, S.T. 1981. How teachers design their materials: Implications for instructional design. Instructional Science 10(4): 363-378. https://doi.org/10.1007/ bf00162734

LeBlanc, M.D., and B.D. Dyer. 2003. Teaching together: A three-year case study in genomics. Journal of Computing Sciences in Colleges 18(5):85-95. https://doi.org/10.5555/771832.771848 
Lindner, J.R., T.H. Murphy, and G.E. Briers. 2001. andling nonresponse in social research. Journal of Agricultural Education 42(4):43-53. https://doi. org/10.5032/jae.2001.04043

Maull, K.E., M.G. Saldivar, and T. Sumner. 2010. Online curriculum planning behavior of teachers. The 3rd International Conference on Educational Data Mining, Pittsburgh, PA. USA. https://dblp.org/rec/conf/edm/MaullSS10 [Cited 1/21/2019]

Moore, J.A., and B. Chae. 2007. Beginning teachers' use of online resources and communities. Technology, Pedagogy and Education 16(2):215-224. https:// doi.org/10.1080/14759390701406844

Oliver, J.S., and G.W. Hodges. 2014. Rural science education. Pages 266-283 in N.G. Lederman and S.K. Abell, editors. Handbook of Research on Science Education,. Routledge Publiching, New York, NY.

Prestridge, S. 2019. Categorising teachers' use of social media for their professional learning: A self-generating professional learning paradigm. Computers \& Education 129:143-158. https://doi.org/10.1016/j.compedu.2018.11.003

Purcell, K., A. Heaps, J. Buchanan, and L. Friedrich. 2013. How teachers are using technology at home and in their classrooms. Pew Research Center's Internet \& American Life Project, Washington, DC. Available from https:// www.pewresearch.org/internet/2013/02/28/how-teachers-are-using-technology-at-home-and-in-their-classrooms/ [Cited 01/21/2019].

Recker, M., A. Walker, S. Giersch, X. Mao, S. Halioris, B. Palmer, D. Johnson, H. Leary, and M.B. Robertshaw. 2007. A study of teachers' use of online learning resources to design classroom activities. New Review of Hypermedia and Multimedia 13(2):117-134. https://doi.org/10.1080/13614560701709846

Ricketts, J.C., D.W. Duncan, and J.B. Peak. 2006. Science achievement of high school students in complete programs of agriscience education. Journal of Agricultural Education 47(2):48-55. https://doi.org/10.5032/jae.2006.02048

Scales, J., R. Terry, Jr., and R.M. Torres 2009. Are teachers ready to integrate science concepts into secondary agriculture programs? Journal of Agricultural Education 50(2):100-111. https://doi.org/10.5032/jae.2009.02100

Schneider, R.M., and J. Krajcik. 2002. Supporting science teacher learning: The role of educative curriculum materials. Journal of Science Teacher Education 13(3):221-245. https://doi.org/10.1023/a:1016569117024

Shepardson, W.H. 1929. Agricultural education in the United States. The Macmillan Company, New York, NY.

Taylor, J.A., S.R. Getty, S.M. Kowalski, C.D. Wilson, J. Carlson, and P.V. Scotter. 2015. An efficacy trial of research-based curriculum materials with curriculum-based professional development. American Educational Research Journal 52(5):984-1017. https://doi.org/10.3102/0002831215585962

Thompson, G.W. 1998. Implications of integrating science in secondary agricultural education programs. Journal of Agricultural Education, 39(4):76-85. https://doi.org/10.5032/jae.1998.04076

True, A.C. 1897. Popular education for the farmer in the United States. Pages 279-290 in Yearbook of the Department of Agriculture. United States Department of Agriculture, Washington, DC. 
Appendix 1: Survey Instrument

How would you classify the community in which your school is located?

1. rural farming community

2. rural non-farming community

3. urban community

How many students are enrolled at your school?

1. less than 50

4. $151-200$

7. 301 or more

2. $51-100$

5. 201-250

3. $101-150$

6. 251-300

What is your sex?

1. male

2. female

What grades do you teach? (select all that you would teach in a normal school year)
1. K-5
4. 8 th
7. 11 th
2. 6 th
5. 9 th
8. 12 th
3. 7 th
6. 10th

How many years have you been teaching?

$\begin{array}{lllll}1.1 & 7.7 & 13.13 & 19.19 & 25.25 \\ 2.2 & 8.8 & 14.14 & 20.20 & 26.26 \\ 3.3 & 9.9 & 15.15 & 21.21 & 27.27 \\ 4.4 & 10.10 & 16.16 & 22.22 & 28.28 \\ 5.5 & 11.11 & 17.17 & 23.23 & 29.29 \\ 6.6 & 12.12 & 18.18 & 24.24 & 30.30\end{array}$

What subjects are you certified to teach? (select all that you are certified to teach)

1. Science

2. Agriculture

3. Other, please list

Are you teaching agricultural courses for science credit?

1. yes

2. no

3. N/A

If you are an agricultural educator, what if any courses do you teach for science credit? 
If you are a science educator, what agricultural topics do you include in your curriculum?

How often do you use social media for educational purposes?
1. Never
4. Once a week
2. Less than once a month
5. Multiple times a day
3. 2-3 times a month
6. Daily

Which social media applications do you use?
1. Facebook
6. Online Professional Learning Community
2. Twitter
7. Other
3. Instagram
4. Snapchat
5. Blogs

What are the five most common places you go to find curriculum resources?

How do you evaluate an online curriculum resource for credibility?

What key components do you look for in a curriculum resource?

Do you bring guest speakers into your classes?
1. yes
2. no

Have you ever had a guest speaker come into your classes remotely? (Skype, Google Hangouts, or similar app)
1. yes
2. no

If you use guest speakers, why do you bring them in?

If you use guest speakers, how often do you have guest speakers in your classroom?

1. once a semester

2. 2-3 times a semester

3. more than 4 times a semester 
How important are the following when selecting a curriculum?

\begin{tabular}{|l|c|c|c|c|c|c|c|c|c|c|}
\hline & \multicolumn{4}{|c|}{ No Importance } & \multicolumn{4}{|c|}{ Great Deal of Importance } \\
\hline $\begin{array}{l}\text { Prior personal experience } \\
\text { with the content }\end{array}$ & 1 & 2 & 3 & 4 & 5 & 6 & 7 & 8 & 9 & 10 \\
\hline Degree of comfortwith the content & 1 & 2 & 3 & 4 & 5 & 6 & 7 & 8 & 9 & 10 \\
\hline Tied to state standards & 1 & 2 & 3 & 4 & 5 & 6 & 7 & 8 & 9 & 10 \\
\hline Tied to national standards & 1 & 2 & 3 & 4 & 5 & 6 & 7 & 8 & 9 & 10 \\
\hline Relevance to your community & 1 & 2 & 3 & 4 & 5 & 6 & 7 & 8 & 9 & 10 \\
\hline Relevance to your students & 1 & 2 & 3 & 4 & 5 & 6 & 7 & 8 & 9 & 10 \\
\hline $\begin{array}{l}\text { Comprehensiveness of the } \\
\text { resources (Lesson Plans, } \\
\begin{array}{l}\text { Presentations, Assessments, } \\
\text { Activities, Equipment lists, etc.) }\end{array}\end{array}$ & 1 & 2 & 3 & 4 & 5 & 6 & 7 & 8 & 9 & 10 \\
\hline
\end{tabular}

How much do the following impact your selection of topics for inclusion in your curriculum?

\begin{tabular}{|l|c|c|c|c|c|c|c|c|c|c|}
\hline & \multicolumn{4}{|c|}{ No Importance } & \multicolumn{4}{|c|}{ Great Deal of Importance } \\
\hline Prior experience with the topic & 1 & 2 & 3 & 4 & 5 & 6 & 7 & 8 & 9 & 10 \\
\hline Comfort with the topic & 1 & 2 & 3 & 4 & 5 & 6 & 7 & 8 & 9 & 10 \\
\hline Listed in the state/ national standards & 1 & 2 & 3 & 4 & 5 & 6 & 7 & 8 & 9 & 10 \\
\hline
\end{tabular}

How often do your students work on independent student selected inquiry projects:

1. Weekly

2. Monthly

3. Once a semester

4. Only in capstone courses

Which of the following do your students participate in as a part of your classes:

1. Eastern SD Science and Engineering Fair

2. Agriscience Fair

3. Local Science Fair

4. My students don't participate in science fairs as a part of class

5. Agricultural Issues Forums

6. Problem Based Learning

Where do you look for additional training/in-service for topics about which you have limited personal experience? 
Comments/Suggestions:

Have you taught about climate change or global warming in any of your courses?

1. yes

2. no

What Comments/Suggestions would you give related to the creation, posting, or sharing of SDSU created curriculum resources?

Is there anything else we should consider in the area of curriculum?

I would like to have links sent to me to agriculture and science curriculum resources SDSU creates as they become available.

1. yes

2. no 